\title{
NOTE
}

\section{GENETIC RELATEDNESS OF Desmodus rotundus FROM NORTHERN URUGUAY WITH POPULATIONS FROM THE REMAINDER OF ITS DISTRIBUTION RANGE}

\author{
Arley Camargo' ${ }^{1}$ Rosana Olivera², Miguel Santiago² \& Julio C. González ${ }^{3}$ \\ 1 Centro Universitario de Rivera, Universidad de la República, Rivera 40000, Uruguay \\ 2 Centro Regional de Profesores del Norte, ANEP-CEF, Rivera 40000, Uruguay \\ 3 Dirección Departamental de Salud, Ministerio de Salud Pública, Rivera 40000, Uruguay
}

\begin{abstract}
The common vampire bat (Desmodus rotundus), which is distributed across most of the Neotropical region, is a reservoir of the rabies virus. In Uruguay, there have been recent reports of paralytic rabies in cattle transmitted by the common vampire bat. We sequenced the cytochrome b gene of five bats from northern Uruguay. All five DNA sequences were identical and grouped with a southern Atlantic Forest clade, suggesting recent dispersal from nearby Brazil, as revealed in phylogeographic diffusion analysis.
\end{abstract}

Keywords: vampire bat, rabies, phylogeography

\section{RESUMEN}

Afinidad genética de Desmodus rotundus (Mammalia: Chiroptera) del norte de Uruguay con poblaciones del resto de su rango de distribución. El murciélago vampiro común (Desmodus rotundus), que se distribuye en la mayor parte de la región Neotropical, es un reservorio del virus de la rabia. En Uruguay han habido reportes recientes de rabia paralítica en ganado transmitido por el murciélago vampiro común. Secuenciamos el gen citocromo b de cinco murciélagos del norte de Uruguay. Todas las secuencias fueron idénticas y agrupadas con el clado Bosque Atlántico Sur, sugiriendo dispersión reciente desde el vecino Brasil, tal como se encuentra en un análisis de difusión filogeográfica.

Palabras clave: murciélago vampiro, rabia, filogeografía

The common vampire bat (Desmodus rotundus) is distributed across most part of the Neotropical region, ranging from $28^{\circ} \mathrm{N}$ to $33^{\circ} \mathrm{S}$, including Mexico south through Central America to Uruguay, Argentina, and Chile. It is a reservoir of the rabies virus, which transmits to its prey during foraging, especially cattle propitiated by its high availability and low mobility, which represents a major economic impact in Latin America (Lee et al., 2012). In Uruguay, reports of paralytic rabies in cattle transmitted by $D$. rotundus have been published from the northern part of the country in 2007 after a gap of 25 years without known incidents (Guarino et al., 2013). There have been additional outbreaks in recent years from the same region including Rivera, Tacuarembó, and Cerro Largo departments (World Organization for Animal Health, WAHIS database). The vampire bat roosts in rocky caves, grottoes, and tree holes throughout Uruguay, but especially in the hilly terrain of the northern and eastern portions of the country, as well as along the Uruguay River (González \& Lanfranco, 2010; Queirolo, 2016).

A recent study assessed the phylogeographic structure of the vampire bat across its distribution range using DNA sequences of the mitochondrial cytochrome b (cytb) gene (Martins et al., 2009). Five major clades were found: Central America (CA), Panamá (PAN), Amazon and Cerrado (AMC), North Atlantic Forest (NAF), and South Atlantic Forest (SAF). The southernmost samples included in that study were collected in Itaqui and Alegrete, eastern Rio Grande do Sul State (RGS, Brazil), but the authors did not include any localities from the southeastern limit of the distribution in Uruguay. Herein, we sequenced the cytb of five vampire bats collected in northern Uruguay to ascertain their genetic relatedness with those of other parts of the species range, in order to infer possible migration routes to Uruguay from neighboring populations in Brazil.

Samples were obtained from five individuals (ear clips) collected on August 10th, 2016 from a hillside rock cave located in 'El Gaire', between the Paso del Cerro village and National Highway 5, Department of Rivera, Uruguay (310 27' 40.6"' S, 550 43' 37.8'" W). Tissues were stored in $95 \%$ ethanol and were processed with the Quick-gDNA MiniPrep kit (Zymo Research) to extract whole genomic DNA after digestion with proteinase $\mathrm{K}$ at $56 \stackrel{\circ}{\circ}$. Next, we amplified two fragments of the cytb gene using the same primers and thermocycling conditions of Martins et al. (2009). After amplification, PCR products were visualized with UV light after an electrophoretic run in a $0.7 \%$ agarose gel stained with GoodView (SBS Genetech). Amplicons were purified with GeneJET PCR Purification kit (Thermo Fisher Scentific) and sent to Macrogen (www.macrogen.com) for direct Sanger sequencing. Nucleotide sequences were checked by inspecting 


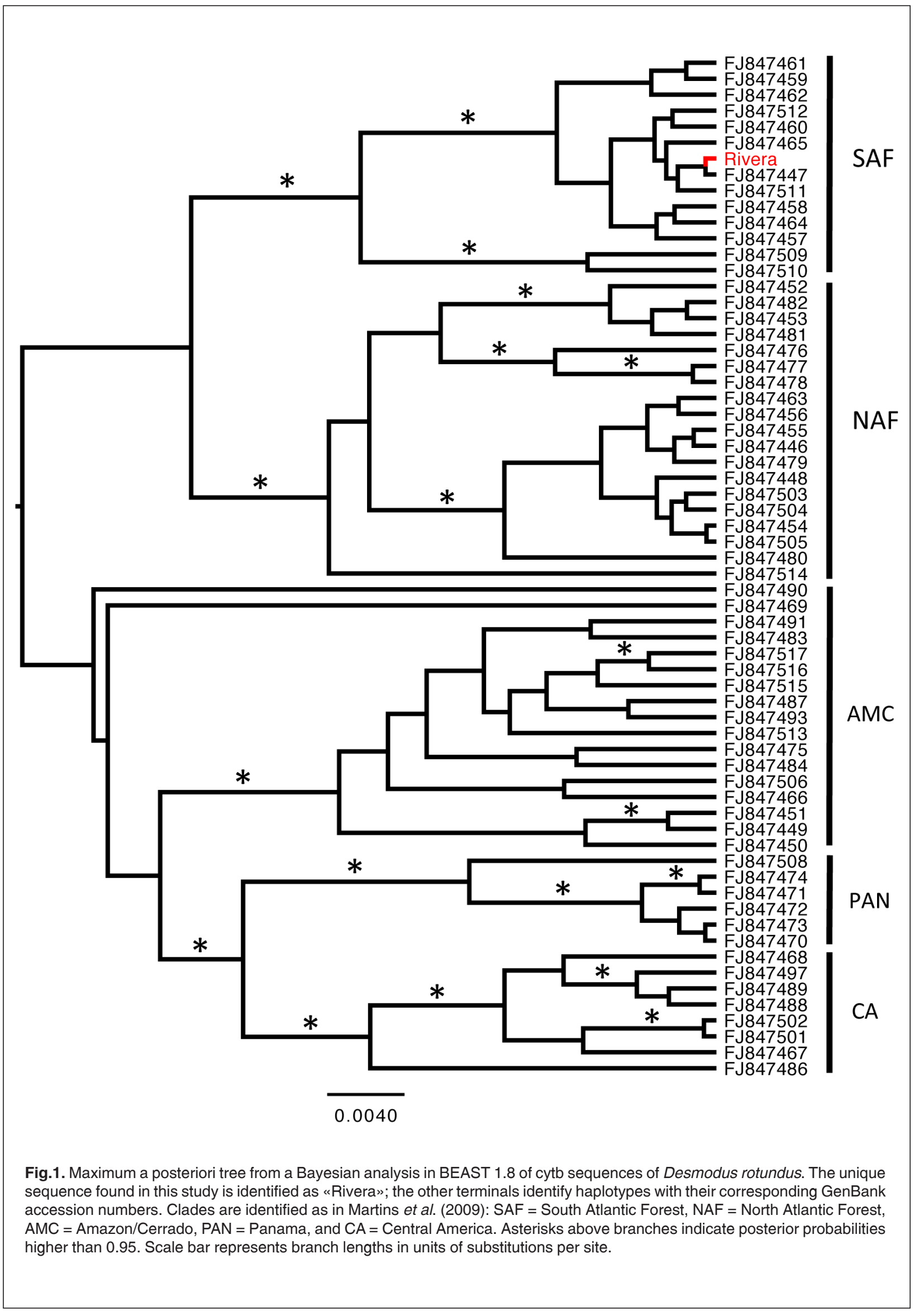

Bol. Soc. Zool. Uruguay (2ª época). 2018. Vol. 27 (1): 14-18 ISSN: 0255-4402 
chromatograms in Geneious 8.1.6 (Biomatters Ltd.) and aligned with homologous sequences of Martins et al. (2009) retrieved from GenBank (www.ncbi.nlm.nih.gov) using Clustal X (Larkin et al., 2007). Sequences were collapsed into unique haplotypes using TCS (Clement et al., 2000). The best-fit substitution model was determined with jModeltest2 (Darriba et al., 2012). A phylogenetic analysis was carried out without an outgroup in BEAST 1.8 because this software estimates rooted trees (Drummond et al., 2012). We set a log-normally distributed, relaxed clock, together with a coalescent Skyride tree prior, and MCMC approximation of the posterior distribution of trees based on 10 million states sampled every 1,000 states. Stationarity and autocorrelation of MCMC samples were checked in Tracer 1.6 (http://tree.bio.ed.ac.uk/software/tracer/), and a consensus tree was summarized with TreeAnnotator 1.8 (Drummond et al., 2012) after discarding a burn-in of 1,000 trees. Finally, in order to infer ancestral geographic locations we implemented a phylogeographic diffusion analysis of the SAF clade in BEAST 1.8 based on a relaxed and continuous random walk model (Lemey et al., 2010). We used all samples included in this clade and their geographic coordinates obtained from Martins et al. (2009). All priors were set as above and the summary consensus tree was annotated with ancestral locations in SpreaD3 (Bielejec et al., 2016) to produce an animation of the diffusion process for visualization in Google Earth.

The cytb sequences of the five vampire bats sequenced in this study, collected from a single cave in El Gaire, were identical to each other (GenBank accession number: MF770712). We combined the complete dataset of Martins et al. with our own data to obtain the final matrix containing 64 sequences of 806 base-pairs, representing a good coverage of the whole distribution of the species, although with low sampling density. After collapsing the sequences, the haplotype found in El Gaire was the same as one (D2; FJ847447) of those found by Martins et al. (2009), which is falls within the SAF clade of our phylogenetic tree (see Fig. 1 and Appendix). In Brazil, this haplotype is found in Itaqui and Alegrete (RGS), in the southern Paraná and Santa Carina States, as well as in several localities of São Paulo State and at one locality in Minas Gerais State. Because haplotype D2 is common and widely distributed within the range of the SAF clade, especially in its southern region, we suggest that a southward range expansion could account for the pattern of haplotype distribution. This idea is reinforced by the typical shallow topology of the SAF clade associated with demographic expansion events as a result of a few common haplotypes and multiple rare haplotypes separated by few mutations (see $p$. 123 in Wakeley, 2009). Moreover, our phylogeographic diffusion analysis strongly supports a history of dispersal of the D2 haplotype that began in southeastern Brazil, followed by dispersal to southern Brazil, and then a further expansion towards Uruguay (Fig. 2). Therefore, our results suggest that the bat colony found in El Gaire is probably the result of dispersal from a neighboring population in RGS. While we cannot discard dispersal from populations farther north in Paraná and Santa Catarina States, which share the haplotype D2 with RGS and Uruguay, it is more likely that dispersal events took place from nearer localities (e.g., Alegrete is roughly $185 \mathrm{~km}$ from El Gaire). However, due to the low sampling density of Martins et al. (2009) and the widespread occurrence of the haplotype D2 in the SAF clade, we cannot evaluate whether El Gaire population has been colonized from a single or multiple population sources. In addition, although we did not evaluate the timing of events, we do emphasize that the expansion towards Uruguay, accounted by the D2 haplotype, is a recent event within the history of the SAF clade of $D$. rotundus. We should be cautious about these inferences because they were based on a single locus, and we cannot discard that the observed pattern could be the result of a selective sweep of the mitochondrial genome (Ballard \& Whitlock, 2004). Having said that, we note that there have been very few phylogeographic studies in the Pampas, particularly in Uruguay and RGS, but several of those recent studies suggest, for several taxa, close affinity and/or recent expansions within this region (Turchetto et al., 2014; Langone et al., 2016; Da Silva Santos et al., 2018).

Rabies is endemic in Brazil while cattle rabies is common in RGS with multiple outbreaks (Prato, 2012; Itou et al., 2016). In northern Uruguay, there have been recent outbreaks of rabies in cattle in locations proximate to the border with RGS (Guarino et al., 2013). Although neighboring bat populations in RGS are the most likely source, other populations farther north could also be potentially contributing migrants to Uruguay based on the widespread distribution of the D2 haplotype. In this respect, it is interesting to consider that genetic studies of the rabies virus in the region have shown that the strains from Uruguay (from the 2007 outbreak, Guarino et al., 2013) were related to strains from the mountainous area of São Paulo and Minas Gerais States (lineages R2/R3, see Itou et al., 2016). Therefore, further sampling of vampire bat populations and nuclear markers are needed to ascertain if local populations in Uruguay consist of unique or multiple lineages originated from multiple populations in RGS. Moreover, we encourage further population genetics studies of the vampire bat (and also of the rabies virus) in the region to better understand the phylogeographic structure and dynamics of the vector, which could help understanding the bat population source and the potential strain identity of future rabies outbreaks. 

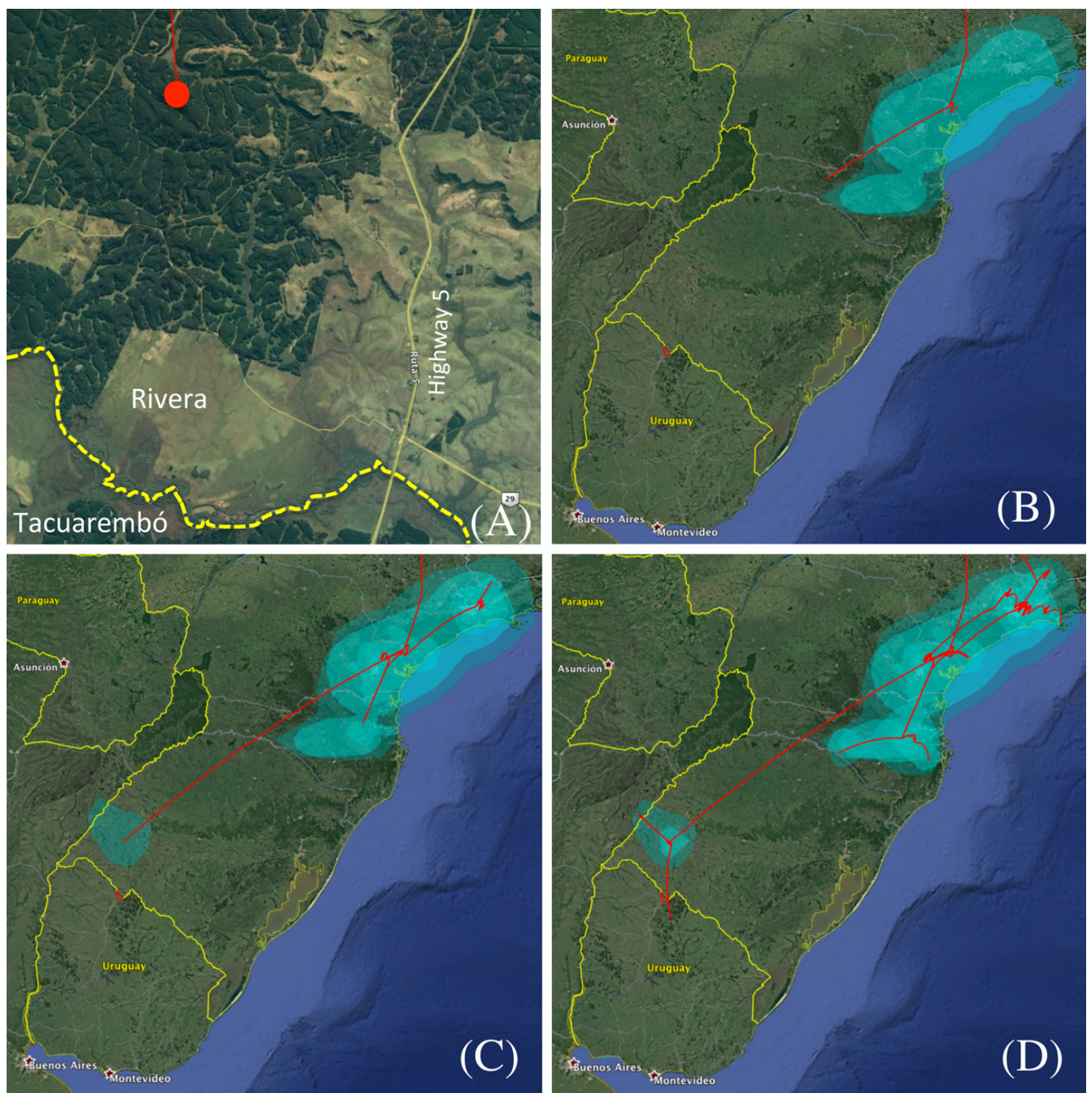

Fig. 2. Maps of the study area and of the phylogeographic diffusion analysis. (A) Map showing the location (red dot) where the vampire bats were collected in Department of Rivera, northern Uruguay. (B) Diffusion reconstruction showing the origin of the SAF clade in southeastern Brazil; (C) dispersal of the D2 haplotype to southwestern RGS (Itaqui and Alegrete); and (D) dispersa of the D2 haplotype to northern Uruguay. Red lines represent the branches of the maximum a posteriori tree and the light blue areas represent $80 \%$-contours of the inferred location of internal nodes.

\section{APPENDIX}

DNA sequence alignment and phylogenetic tree in TreeBASE repository:

http://purl.org/phylo/treebase/phylows/study/ TB2:S21467

\section{ACKNOWLEDGMENTS}

We thank the associate editor G. D'Elía and two anonymous reviewers for detailed comments and suggestions that improved an original version of the manuscript.

\section{REFERENCES}

Ballard J.W. \& Whitlock M.C. 2004. The incomplete natural history of mitochondria. Molecular Ecology, 13(4): 729-744.

Bielejec F., Baele G., Vrancken B., Suchard M.A., Rambaut A. \& Lemey P. 2016. SpreaD3: Interactive visualization of spatiotemporal history and trait evolutionary processes. Molecular Biology and Evolution, 33(8): 2167-2169.

Clement M., Posada D. \& Crandall K. 2000. TCS: a computer program to estimate gene genealogies. Molecular Ecology, 9(10): 16571660. 
Darriba D., Taboada G.L., Doallo R. \& Posada D. 2012. jModelTest 2: more models, new heuristics and parallel computing. Nature Methods, 9(8): 772.

Da Silva Santos A., Trigo T.C., de Oliveira T.G., Silveira L. \& Eizirik E. 2018. Phylogeographic analyses of the pampas cat (Leopardus colocola; Carnivora, Felidae) reveal a complex demographic history. Genetics and Molecular Biology. 2018;41(1 Suppl. 1): 273-287.

Drummond A.J., Suchard M.A., Xie D. \& Rambaut A. 2012. Bayesian phylogenetics with BEAUti and the BEAST 1.7. Molecular Biology and Evolution, 29(8): 1969-1973.

González E.M. \& Martínez Lanfranco J.A. 2010. Mamíferos del Uruguay: Guía de campo e introducción a su estudio y conservación. Banda Oriental, Vida Silvestre \& MNHN, Montevideo. 464 pp.

Guarino H., Castilho J.G., Souto J., de Novaes Oliveira R., Carrieri M.L. \& Kotait I. 2013. Antigenic and genetic characterization of rabies virus isolates from Uruguay. Virus Research, 173(2): 415420.

Itou T., Fukayama T., Mochizuki N., Kobayashi Y., Deberaldini E.R., Carvalho A.A.B., Ito F.H. \& Sakai T. 2016. Molecular epidemiological tracing of a cattle rabies outbreak lasting less than a month in Rio Grande do Sul in southern Brazil. BMC Research Notes, 9: 87.

Langone J.A., Camargo A. \& de Sá R.O. 2016. High genetic diversity but low population structure in the frog Pseudopaludicola falcipes (Hensel, 1867) (Amphibia, Anura) from the Pampas of South America. Molecular Phylogenetics and Evolution, 95(1): 137-151.

Larkin M.A., Blackshields G., Brown N.P., Chenna R., McGettigan P.A., McWilliam H., Valentin F., Wallace I.M., Wilm A., Lopez R., Thompson J.D., Gibson T.J. \& Higgins D.G. 2007. Clustal
$\mathrm{W}$ and Clustal $\mathrm{X}$ version 2.0. Bioinformatics, 23(21): 2947-2948.

Lee D.N., Papes M. \&Van Den Bussche R.A. 2012. Present and potential future distribution of common vampire bats in the Americas and the associated risk to cattle. PLoS ONE, 7(8): e42466.

Lemey P., Rambaut A., Welch J.J. \& Suchard, M.A. 2010. Phylogeography takes a relaxed random walk in continuous space and time. Molecular Biology and Evolution, 27(8): 1877-1885.

Martins F.M., Templeton A.R., Pavan A.C.O., Kohlbach B.C. \& Morgante J.S. 2009. Phylogeography of the common vampire bat (Desmodus rotundus): marked population structure, Neotropical Pleistocene vicariance, and incongruence between nuclear and mtDNA markers. BMC Evolutionary Biology, 9: 294.

Prato R.P. 2012. Vigilância da Raiva Humana. In: Cardoso J.C. (Ed.), Raiva no Rio Grande do Sul. Boletim Epidemiológico 15(1): 6-10.

Queirolo D. 2016. Diversidade e padrões de distribuição de mamíferos dos campos do Uruguai e sul do Brasil. Boletín de la Sociedad Zoológica Uruguay, 2da época, 25(2): 92-146.

Turchetto C., Fagundes N.J., Segatto A.L., Kuhlemeier C., Solís Neffa V.G., Speranza P.R., Bonatto S.L. \& Freitas L.B. 2014. Diversification in the South American Pampas: the genetic and morphological variation of the widespread Petunia axillaris complex (Solanaceae). Molecular Ecology, 23(2): 374-389

Wakeley J. 2009. Coalescent Theory: An Introduction. Roberts \& Company Pubs., Greenwood Village. XII +326 pp.

Fecha de Recepción: 11 de Setiembre de 2017 Fecha de Aceptación: 16 de Julio de 2018 